\title{
Modern Economization-Only a Burden on Diaconia and Church?
}

\author{
Andreas Pawlas \\ Department of Theology, University of Tartu, Tartu, Estonia \\ Email: Andreas.Pawlas@web.de
}

Received 17 January 2014; revised 17 February 2014; accepted 28 February 2014

Copyright (C) 2014 by author and Scientific Research Publishing Inc.

This work is licensed under the Creative Commons Attribution International License (CC BY). http://creativecommons.org/licenses/by/4.0/

(c) (i) Open Access

\begin{abstract}
Although Diaconia/Caritas and Protestant/Roman Katholic Churches are large service providers in Germany, they often feel economic thinking as a burden or even a nuisance. It is regarded as something "not authentic" in the aid and assistance to the poor, miserable and needy as successors in the love of Jesus Christ. But economic thinking has to be seen as careful handling of the entrusted goods and is justified in the sense of belief in creation and the "Two Natures Doctrine" of Christ. It must be regarded as an important expression of all the earthly. On the other hand an exclusively economic profit-oriented attitude easily can turn in greed and avarice. And that makes it blind not only for the responsibility to one's neighbor and but also for essential risks. Therefore many companies went to develop their own "corporate culture", in which should be deployed the ethical principles of the companies. However in the companies of the Diaconia it is not necessary to develop new ethical principals because diaconal work should be founded in a "culture of charity" of Christianity that creates engaged employees.
\end{abstract}

\section{Keywords}

Diaconia, Christian Social Work, Business Ethics, Charity, Corporate Culture

\section{Introduction}

Few people are aware that Diaconia/Caritas and Protestant/Roman Catholic Churches are one of the largest service providers in Germany. With more than 1,000,000 employees they are one of the biggest corporate organizations. Nevertheless economic thinking and patterning [1] there is often felt as a burden or even a nuisance. Because many engaged Christians working in Diaconal institutions cannot accept economic thinking in the face of a poverty-orientation they are committed from their self-understanding as Christians [2].

However in view of a) dwindling funds, b) the abolition of automatically cover deficit procedures by (qua- 
si-)governmental bodies and c) increasing competition, economic processes to reduce costs are strictly prescribed [3] and also wanted [4]. Otherwise, e.g. many of the small diaconal hospitals run in the risk to perish economically by the current conversion to DRGs (Diagnosis Related Groups) [5].

Beyond this ways economic thinking also makes its entrance in some German Diaconal institutions under the demands of a "professionalization".

Anyway, too often the economic pressure built up by this is generating mutual distrust between management and employees and creates a climate of invidious competition [6]. Overall therefore the complaint rises that economic issues are pushing everything else to the background. And some feel the pressure by the forced changes so overwhelming that it seems to deprive them of the conditions under which they have started then their social work in Diaconia and Church.

Now it must not necessarily be comforting for all concerned to observe that such comprehensive orientation in economic terms affects not only the ecclesiastical and diaconal work, but also the society as a whole. And to answer the question about the background of this development, meanwhile it is apparently no longer sufficient to refer solely to the principle specified limitation of all necessary means. The unprecedented success story is much more powerful that can boast the economic occidental thought in the last two hundred years-what did not very impress Diaconia and Church for a long time.

\section{Christian Witness and Economic Responsibility}

Because it was thought at the church and diaconal working fields (in the Protestant Tradition as well as in the Roman Catholic Tradition) for a long time that the economic aspects of life were to regard as something "not authentic" and were to neglect as not belonging to the core of the churchly and diaconal job properly or even were to fade out. Diaconia seemed to be too lofty as "aid and assistance to the poor, miserable and needy as a 'successor in the love of Jesus Christ"” [7], against "filthy lucre". And many felt encouraged by appropriate warnings or even threats from the biblical witness, culminating in the well-known passage: "You can not serve God and mammon" [Matthew 6:24]. And they could also feel support by Martin Luther, who could make sharp polemics e.g. against the money: "The current money can despise the present God" [8] or "Where is great wealth and power, there are also great sins and wrongs. Money makes the thief” [9].

However, Luther can by no means ignore the fact that a careful handling of the entrusted goods entirely belongs to Christian life and must be understood as a responsible stewardship, as is seen in the New Testament [10]. Because Jesus himself just not was a propertyless "itinerant charismatic" [11] despising everything economic.

To that extent the economic has to be seen as justified in the sense of belief in creation [12] and the two natures doctrine [13] and must be regarded as an important expression of all the earthly, and thus as part of the humanum-in its embedding in the particular socio-economic social environment [14]. In this respect, it is to accept soberly that to some extent the popular sentence of Walther Rathenau "Economics is the fate of" [15] is theological justified, who thus described the centrality of economic activity for daily life under the conditions of modern societies [16].

On the other hand it would mean the surrender of Diaconia and Church, if the whole of our reality and the reality of God would be particularly described by this sentence of Rathenau. Therefore, the reflection on this perception and conviction actually should encourage Christianity relying on that the spiritual motives and impulses are the relevant and remain in comparison to the economic. Due to this reason-that is enshrined for all eternity, and despite the current popularity of economic thinking, its success story and its necessities—all diaconal workers should have really good reason to be confident and grateful.

\section{Success and Crisis of Economic Ways of Thinking}

That should be emphasized now not only because of the shock, a purely economic profit-oriented attitude has come under the current economic and financial crisis. However, in this crisis had been clearly revealed how easily an exclusively economic profit-oriented attitude can turn in greed and avarice. And that makes it not only blind for the responsibility to one's neighbor and but also for essential risks.

Nevertheless - what was perceived in Diaconia and Church hardly-there were to recognize important decisions to a change in economic thinking at the beginning of the 1980s. This change was preceded, however, that since the beginning of the 20th century that distance between "value orientation" and "objective science" as by 
Max Weber once requested in the interests of "value freedom of science" [17] was widespread and had become effective. And that led to a rift between theology as an advocate of value orientation and the economy as a lawyer of "eigengesetzlicher" (acting after own inherent/autonomous laws) [18] economic principles. And then the following concentration of the economy on its "Eigengesetzlichkeiten" [19] (own inherent/autonomous laws) undoubtedly was extremely successful.

However then had to be discovered at the beginning of the 1980s and under its exclusive focus on economics and profit orientation that the employees personally lost those values that were necessary to maintain an orderly company-production process. The dimensions of feeling responsible and the sense of care and of duty were no longer present such as they should have been. Obviously this was an effect years ago pointed out by the socalled "Böckenförde dictum" [20] which was first concerning the secular state ("The liberal, secular state lives on conditions which he itself can not guarantee.”) but even was valid for the companies in the secular society.

\section{The Power of a "Culture of Charity"}

This development then for many companies was the opportunity to ask questions to theology and church, to give aid by ethical orientation to the working people in the country. In the following years some Protestant Economic Ethics [21] were developed and also, from a Catholic [22] or philosophical [23] perspective, economic ethics were presented [24]. But the most remarkable result is that currently the sharp dissociation between value orientation and objective science in the interests of "value freedom of science" launched by Max Weber is clearly resolved.

And what Max Weber appeared unthinkable now occurs in a plethora of companies: namely, that they seek to develop their own "corporate culture", in which should be deployed the ethical principles of the companies. Nowadays the literature on this nearly has become unmanageable. And the efforts and costs are significant to develop this as obviously necessary perceived "soft skills" in the company.

Interestingly, in Germany there are also efforts to diaconal "corporate culture" and the development of a "Social Service Agency Governance Code" in 2005. In line with the German corporate governance system it has to "describe the major foundations to strengthen the diaconal institution culture, especially by improving the management and supervision of diaconal institutions". It is amazing though it expressly found the obligation to "respect of business principles in the management of the facilities," but no mention of the traditional Christian diaconal basics [25]. Should here diaconal leaders still be captured by obsolete categories of Weberian embossing?

And yet, in contrast to the trends in many economic enterprises Diaconia should be proud and grateful that the elements of the corporate culture must not be newly discovered and must not be functionalized in its working areas [26] "for the competitive profile of Diaconia on the social market" and for a "strong Christian identity development", because from the beginning of Christianity it was present and often in a deliberate spiritual character [27].

Merely concerning the economical process result of such revival of the Diaconal corporate culture could be an improvement of the "soft skills", which simply could reduce personnel costs:

1) Because in this case the force of economic pressure could not induce such mutual distrust between management and employees as usual in other companies. That could not only save costs in controlling but even avoid court disputes.

2) Because in this case employees in Christian identity are motivated mainly intrinsic. That means they are not only working to earn their money for themselves but they also work to serve the Lord [28] and—as Luther highlights - to be happy about this [29]. Therefore such employees are more engaged, probably are less sick, and stick together with their diaconal management to help the poor, ill and helpless people-even under the conditions of modern economy.

However, it is a permanent task to cultivate this Christian base of diaconal work in a "culture of charity". And the challenge is great, here not to bend or functionalize souls [30], but to escort spiritually appropriate and wooing. Because if diaconal aid is to be genuine, it must come from the heart, from the centre of the person, and therefore can never be commanded. And that is one of the main ideas of the variously discussed traditional idea of the "Dienstgemeinschaft" [31] (community in service) and especially of the Lutheran concept of calling [32]. Fortunately everything is already in place, what elsewhere has to be worked out with a lot of efforts that pure economization is not self-destructing. This "eternal" advantage of Diaconia, living from the orientation of the 
Bible and therefore to be "innovative from a living tradition" [33] is reason for gratitude and should never be lost sight of.

\section{References}

[1] Haslinger, H. (2009) Diakonie: Grundlagen für die soziale Arbeit der Kirche. Paderborn, 147.

[2] Fleßa, S. (2005) Armutsorientierung in der Diakonie? Betriebswirtschaftliche Grundlagen eines diakonischen Leistungsprogramms. In: Herrmann, V., Ed., 50 Jahre Diakoniewissenschaftliches Institut, Ergebnisse und Aufgaben der Diakoniewissenschaft, Heidelberg, 70.

[3] Fleßa, S. and Städler-Mach, B. (2001) Konkurs der Nächstenliebe? Diakonie zwischen Auftrag und Wirtschaftlichkeit, Göttingen.

[4] Busch, J. (1991) Controlling und Theologie. Aspekte der Leitungsverantwortung. In: Schibilsky, M., Ed., Kursbuch Diakonie, Neukirchen-Vluyn, 292.

[5] Fleßa, S. (2005) Diskussionsbeitrag. In: Herrmann, V., Ed., 50 Jahre Diakoniewissenschaftliches Institut, Ergebnisse und Aufgaben der Diakoniewissenschaft, Heidelberg, 129.

[6] Meyns, C. (2010) Kirche als synergetisch wirkender Zusammenhang von Religion, Interaktion und Organisation. Vorsicht, Kirche: Nicht betriebswirtschaftlichen Ausblendungen und Kurzschlüssen zum Opfer fallen. NORDELBISCHE STIMMEN, 26.

[7] Wagner, H. (1958) Diakonie. In: RGG II 3, 162.

[8] Luther, M. (1912) Werke. Kritische Gesamtausgabe. Tischreden. Vol. 1, Weimar ff, 2347.

[9] Luther, M. (1897) Werke. Kritische Gesamtausgabe. Vol. 19, Weimar, 381, 4-6.

[10] Baumgarten, J. (2004) Wirtschaft/Wirtschaftsethik IV. Neues Testament. In: TRE 36, 146.

[11] Theißen, G. (1977) Soziologie der Jesusbewegung. Ein Beitrag zur Entstehungsgeschichte des Urchristentums. München, 14,35 .

[12] Baumgarten, J. (2004) Wirtschaft/Wirtschaftsethik IV. Neues Testament. In: TRE 36, 146.

[13] Nüssel, F. (2005) Zweinaturenlehre. In: RGG VIII, 4th Edition, 1934.

[14] Fleßa, S. (2005) Armutsorientierung in der Diakonie? Betriebswirtschaftliche Grundlagen eines diakonischen Leistungsprogramms. In: Herrmann, V., Ed., 50 Jahre Diakoniewissenschaftliches Institut, Ergebnisse und Aufgaben der Diakoniewissenschaft, Heidelberg, 73.

[15] Rathenau, W. (1924) Rede auf der Tagung des Reichsverbandes der deutschen Industrie. Gehalten in München am 28. September 1921. In: Rathenau, W., Ed., Gesammelte Reden, Berlin, 264.

[16] Jähnichen, T. (2008) Wirtschaftsethik. Konstellationen-Verantwortungsebenen-Handlungsfelder. Stuttgart, 9.

[17] Weber, M. (1985) Gesammelte Aufsätze zur Wissenschaftslehre. In: Winckelmann, J., Ed., Tübingen, 149.

[18] Thielicke, H. (1965) Theologische Ethik I. Tübingen, 3rd Edition, 5-14,50-66,589-610.

[19] Weber, M. (1920) Gesammelte Aufsätze zur Religionssoziologie I. Tübingen, 19889, 552.

[20] Böckenförde, W. (1976) Staat, Gesellschaft, Freiheit. Frankfurt, 60.

[21] Pawlas, A. (2000) Die Lutherische Berufs- und Wirtschaftsethik. Eine Einführung. Neukirchen-Vluyn.

[22] Gesellschaft, G. (1999) Handbuch der Wirtschaftsethik. Gütersloh.

[23] Aßländer, M.S. (2011) Handbuch Wirtschaftsethik. Stuttgart/Weimar.

[24] Oermann, N.O. (2014) Wirtschaftsethik—Quo vadis. In ThLZ 139, 4, 411-426.

[25] Diakonie Rheinland-Westfalen-Lippe (2014) Diakonischer Corporate Governance Kodex. http://www.diakonie-rwl.de/cms/media//pdf/service/infomaterial/Diakonie-CGK.pdf

[26] Benedict, H.-J. (2006) Theologische Herausforderungen. In: Diakonisches Werk der Evangelischen Kirche in Deutschland, Ed., Leitbild und Selbstverständnis der Diakonie, Stuttgart, 11.

[27] (2008) The Diaconal Self-Concept Is There Where Professionalism Unfolds in Close Reference to the Questions of Spirituality. In: Diakonisches Werk der Evangelischen Kirche in Deutschland, Ed., Characteristics of Diaconal Culture. Strengthening the Diaconal Profile, Diakonie Texte, 17, 12. http://www.diakonie.de/media/Texte-2008-17-DiaconalCulture.pdf

[28] Die Bibel, S. (1985) With Good Will Doing Service, as to the Lord, and Not to Men. Eph 6.7, 232.

[29] Luther, M. (1911) Werke. Kritische Gesamtausgabe. Bd. 40 I Weimar ... secundum vocationem pro virili facere officium in fide, gaudio, 577. 
[30] Benedict, H.-J. (2006) Theologische Herausforderungen. 11.

[31] Boeckler, R. (2001) Diakonie. In: EKL Bd 1/2, 3rd Edition, 852.

[32] Stümke, V. (2007) Das Friedensverständnis Martin Luthers. Stuttgart, 154.

[33] (1997) Bremen. In: Diakonisches Werk der Evangelischen Kirche in Deutschland, Ed., Leitbild und Selbstverständnis der Diakonie. http://www.diakonie.de/media/Texte-2006-23-Leitbild-Tagung.pdf 